\title{
PALAEOPATHOLOGICAL EVIDENCE OF INFECTIOUS DISEASE IN A SKELETAL POPULATION FROM LATE MEDIEVAL RIGA, LATVIA $\left(15^{\mathrm{TH}}{ }_{-17^{\mathrm{TH}}}\right.$ CENTURIES AD)
}

\author{
Guntis Gerhards $^{1, \#}$, Elīna Pētersone-Gordina ${ }^{1}$, and Zita Krūmiṇa ${ }^{2}$ \\ ${ }^{1}$ Institute of Latvian History, University of Latvia, Kalpaka bulv. 4, Riga, LV-1050, LATVIA \\ ${ }^{2}$ Latvian Biomedical Research and Study Centre, Rātsupītes iela 1, Riga, LV-1067, LATVIA \\ \# Corresponding author; guntis.gerhards@inbox.lv
}

Communicated by Jānis Kloviṇš

\begin{abstract}
The aim of this study was to evaluate the presence of infectious disease in the Dome Church (Riga Cathedral) Cemetery population, dating from the late medieval period $\left(15^{\text {th }}-17^{\text {th }}\right.$ centuries $A D$ ). A total of 274 individuals were macroscopically observed for evidence of infectious disease, and seven individuals with lesions possibly associated with a bacterial infection affecting the skeleton were selected for further analysis. Pathological changes on the outer table of the skull and in the long bones of legs characteristic of venereal syphilis were observed in four female and one male individual. Likewise, changes possibly related to late congenital syphilis were observed in a 14-15-year-old non-adult individual. All these individuals were buried in a small area adjacent to the northern wall of the Dome Church, which possibly belonged to a hospital or a shelter. The evidence for venereal syphilis from the cemetery complements historical data about the spread of the disease in Riga during the $16^{\text {th }}-17^{\text {th }}$ centuries $A D$. One adult male individual had destructive changes in the lower spine, which could be associated with tuberculosis (TB). So far, this is the first individual with possible TB from the archaeological populations of Riga. This research provides unique evidence about infectious disease in skeletal populations from the late medieval period in Latvia, and the results will be used as the basis for future research in the subject, including extraction of ancient pathogen DNA.
\end{abstract}

Key words: palaeopathology, infectious disease, tuberculosis, venereal syphilis.

\section{INTRODUCTION}

Infectious diseases were responsible for a substantial number of deaths in the past populations, especially in overcrowded urban environments (Larsen, 1997). Indeed, mortality rates of the living populations only significantly decreased in the $20^{\text {th }}$ century, when the overall quality of life improved thanks to better nutrition and hygiene, as well as the invention of antibiotics and vaccines (Cronberg, 1986). Although historical sources can provide an insight into the quality of life, morbidity and mortality in the past populations, the primary source of information is palaeopathological analysis of archaeological skeletal remains.

The aim of this paper is to present data about infectious diseases in Riga during the late medieval period, based on skeletal material from the Riga Dome Church Cemetery. Such specific research has not been attempted before, and therefore the results will provide unique evidence about infectious disease in Riga during the period in question, as well as form a basis for further research. Studying the his- tory of epidemics is not only important for understanding the life and death in past populations; learning about the spread and the course of infectious diseases in the past can help to prevent and limit them in living populations. Many of these diseases have not disappeared and still affect people around the world, regardless of the advances of the $21^{\text {st }}$ century medicine, with the same consequences as in antiquity.

The quality and quantity of palaeopathological data depends on a variety of factors, such as funeral practices, the quality and strategy of archaeological excavations, the preservation of skeletal remains in different soil conditions, as well as the processes of bone diagenesis in the ground. Often, the limiting factor in a thorough palaeopathological analysis is fragmentary or poorly preserved skeletal remains. When dealing with historical populations, historical sources such as documents describing certain historic events, diseases and epidemics, medical prescriptions, iconography, as well as data from archaeological excavations and ethnographic data can provide a valuable secondary source of information, the primary source being actual skeletal remains (Rob- 
erts, 2002). Unfortunately, there is a lack of information about years of bad harvests, famines and epidemics in the written sources from late medieval Latvia. Moreover, in the existing chronicles, every epidemic that caused high mortality among the population was described as the plague, which was not always the case (Dunsdorfs, 1962). For a better understanding about outbreaks of infectious disease in the past, it is important to consider the historical context, including the circumstances that could have caused or encouraged the spread of the disease. Listed below are just a few preconditions that could have helped the spread of infectious disease in medieval and late medieval Riga.

Since the very beginning of its foundation in the $13^{\text {th }}$ century, Riga was built as an enclosed city, with a high population density inside the city walls (Šterns, 1997). Occasionally, during disasters such as famines and wars, the city had to accommodate a large number of immigrants, and the overcrowded conditions increased the possibility of epidemics. Infectious diseases spread with the speed of their carriers. In the past, the diseases were carried via trade routes, ports, and by marching armies. In the medieval period Riga was often involved in territorial disputes, which brought foreign armies into its territory. On the other hand, since the city was among the largest trading centres on the Baltic coast, it attracted traders and buyers from all over the region. As a result, the inhabitants of Riga were at high risk of contracting various diseases. According to historical sources, there was a number of infectious diseases affecting the population of Riga during the late medieval period, including typhus, plague, and smallpox (Brennsohn, 1905). Combined with poor nutrition and low quality of life, the diseases greatly reduced the life expectation of the population (Zarina, 2009).

Since the majority of infectious diseases only affect the soft tissue, they are hard to trace in skeletal remains. If, however, the disease has become chronic, instead of causing death shortly after onset, there is a possibility to detect it in the skeleton. Nevertheless, when finding possible infection-related bone changes in skeletal remains it is often difficult to name the cause. This is because the bone response to infection is limited and therefore the changes look similar in a number of conditions. One of the most typical bone responses to soft tissue infection is deposition of new bone on top of existing bone surface (periosteal new bone formation). Such changes, if affecting the skeleton without a particular pattern, are called non-specific. There are, however, chronic infectious diseases to which the human skeleton responds in a particular way, and they are therefore recognisable during palaeopathological analysis. These diseases include leprosy, venereal syphilis, and tuberculosis (TB) (Ortner, 2003).

Leprosy is a chronic infectious disease caused by the bacterium Mycobacterium leprae. The disease mostly affects the skin and nervous system, and only involves the skeleton in $3-5 \%$ of the people affected. The majority of people with leprosy pass away without any related bone changes in the skeleton (Roberts and Manchester, 2005). Despite the fact that the disease is often mentioned in historical sources (Bergmann, 1888), along with specialised leprosy hospitals or leprosaria, the first of which was mentioned in 1225, so far no cases of leprosy have been found in the archaeological populations of Riga. This could be due to the strategy of most archaeological excavations, when skeletal material was not collected completely, leaving smaller bones such as those in hands and feet, behind in the excavation trench. Bone changes specific to leprosy can affect hands and feet (Ortner, 2003), but they are simply not observable in individuals that have not been fully collected. With regards to the skeletal population analysed during this research, however, most bones of hands and feet were available for analysis.

Venereal syphilis (VS) is caused by the bacterium Treponema palladium palladium and it can affect the skeleton in the third stage of the disease after onset, but only in $20 \%$ of those affected. In the majority of cases, the skull and the long bones of legs are involved (Steinbock, 1976). In Riga, skeletal changes possibly caused by VS have been found in the skulls of two individuals from the Dome Church (Derums, 1988). In a wider context, evidence for VS in the late medieval period in Latvia has also been found in skeletal populations from Dobele (Jankauskas, 1994) and Ventspils (Gerhards, 2005).

Tuberculosis (TB) is an infectious disease caused by mycobacteria, particularly Mycobacterium tuberculosis. TB only involves the skeleton in $5 \%$ of all affected individuals during the active stage of the disease. Usually the changes affect the spine, as well as ribs and joints (Ortner, 2003). So far, there is no data about TB in the medieval populations of Riga. Only a small number of individuals with skeletal changes possibly related to TB have been reported in Latvian skeletal populations so far (Derums, 1988).

\section{MATERIAL AND METHODS}

In and around the Riga Dome Church, three burial grounds dating from the medieval and late medieval period were discovered during archaeological excavations, the first inside the church, the second in the courtyard and the cloisters, and the third outside the church. In this study, 274 individuals recovered in 1986-1989 from the third burial ground outside the church, were analysed. During the excavations, the area was already a part of the Dome Square, with no evidence of burials, such as gravestones, above the ground. The oldest part of the cemetery was to the east of the church, but the most recent was located by its northern wall. Apart from individual graves, several collective burials were also uncovered in the most recent part of the cemetery (Tilko, 1998). The archaeologists believe that the third burial ground was reserved for the Bishop's servants, and for the poor. The burials in the third burial ground have been dated to the $13^{\text {th- }} 17^{\text {th }}$ centuries (Tilko, 1998). Overall, the preservation of the skeletal remains was good, but due to the excavation strategy, no ribs were available for analysis. Moreover, some skeletal remains were incomplete due to disturbance of the graves by later burials. 
The age of the adult individuals was estimated mainly by degenerative changes in the pubic symphysis and the auricular surface (Lovejoy et al., 1985; Meindl et al., 1985; Brooks and Suchey, 1990; Buckberry and Chamberlain, 2002). The age of the non-adult individuals was estimated using dental development and eruption, as well as epiphyseal fusion (Scheuer and Black, 2000). Sex was estimated in the adult individuals by observing the morphology of the pelvis and skull (Phenice, 1969; Ascádi and Nemeskéri, 1970; Buikstra and Ubelaker, 1994).

All individuals were observed macroscopically for any changes possibly related to infectious disease (new bone formation, destructive changes, or both), taking into account the appearance and distribution of the lesions (Hackett, 1976; Steinbock, 1976; Ortner and Putschar, 1981; Ortner, 2003).

\section{RESULTS}

The skeletal population consisted of 108 males, 80 females, and 84 non-adults. Unusually for a Christian burial ground, there were only $2.7 \%$ of children younger than four years of age buried in the cemetery, although it is believed that child mortality was very high during the medieval and post-medieval period in Latvia (Zarina, 2009).

During palaeopathological analysis, skeletal changes possibly related to certain infectious diseases were found in six adult and one non-adult individual (Table 1). All seven individuals had been buried by the northern wall of the church, dating from the $15^{\text {th }}-17^{\text {th }}$ centuries AD. The pathological changes found in these individuals are described in more detail below.

Burial 139 (male, 25-30 years old). The entire skeleton was available for analysis, except for the skull and the ribs. There were destructive bone changes in the inferior body of the $5^{\text {th }}$ lumbar vertebra, which had partly destroyed the bone (Fig. 1). The changes also affected the superior and inferior body of the $1^{\text {st }}$ sacral vertebra $(\mathrm{S} 1)$, as well as the superior body of the S2.

Table 1

INDIVIDUALS WITH PATHOLOGICAL CHANGES POSSIBLY RELATED TO CERTAIN INFECTIOUS DISEASES

\begin{tabular}{l|cc|c|c}
\hline $\begin{array}{c}\text { Burial } \\
\text { No. }\end{array}$ & Century, AD & Sex & Age (years) & $\begin{array}{c}\text { Infectious } \\
\text { disease }\end{array}$ \\
\hline 139 & 15 th -16 th & male & $25-30$ & TB \\
185 & 16 th -17 th & female & $40-45$ & VS (?) \\
$209 \mathrm{~d}$ & 16 th -17 th & female & $25-30$ & VS \\
212 & 16 th -17 th & male & $45-50$ & VS \\
214 & $16 \mathrm{~h}-17$ th & female & $35-40$ & VS \\
$217 \mathrm{~b}$ & 15 th -16 th & $?$ & $14-15$ & VS \\
$217 \mathrm{e}$ & 15 th -16 th & female & $30-35$ & VS
\end{tabular}

TB, tuberculosis; VS, venereal syphilis

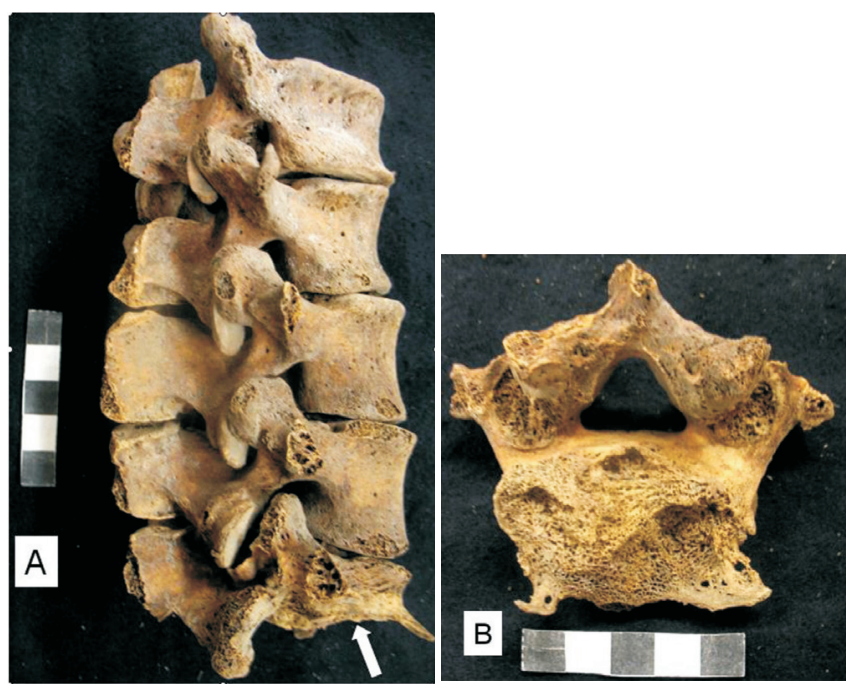

Fig. 1. Individual 139, evidence for spinal tuberculosis: A. right lateral view of the L1-L5 showing partial destruction of the body of L5; B. inferior view of the L5 showing destructive lesions on the body and both pedicles (scale in $\mathrm{cm}$ ).

Burial 185 (female, 40-45 years old). The skeletal remains were fragmentary (the skull, the right arm and leg, and the ribs were absent). There was periosteal new bone formation on the left tibia and fibula, which had caused thickening of the whole shaft. The new bone was partly remodelled.

Burial 209d (female, 25-30 years old). This individual was buried in a collective pit (Burial 209), and the whole skeleton was available for analysis. Several lytic lesions were observed on the outer table of the frontal bone. In the post-cranial skeleton, lytic lesions were present on the articular surface of the humeral head and the sterno-clavicular joint of the right clavicle. Apart from lytic lesions, periosteal new bone formation was present on both tibiae, anteriorly and laterally, and the left femur.

Burial 212 (male, 45-50 years old). The entire skeleton was available for analysis. Similarly to burial 209d, irregular, lytic lesions were present on the frontal bone of this individual. Post-cranially, periosteal lesions were present on both tibiae, and as a result, both shafts were thickened. New bone formation was also present on the femora, as well as posteriorly on the left proximal ulna and the distal epiphysis of the left radius.

Burial 214 (female, 35-40 years old). The entire skeleton was available for analysis. The most obvious pathological changes affected the skull of this individual, particularly the frontal and the facial bones. Lytic lesions were present on the frontal bone, one of which had perforated the bone completely. This lesion was located above the right orbit. The nasal aperture was enlarged due to extensive remodelling of the anterior nasal spine of the maxilla (Fig. 2). A mixture of new bone formation and destructive changes were also present anteriorly on the right zygomatic bone. Post-cranially, periosteal new bone formation and thickening of the shaft was observable on both tibiae and fibulae. New bone formation was also present on the proximal shaft of the right hu- 


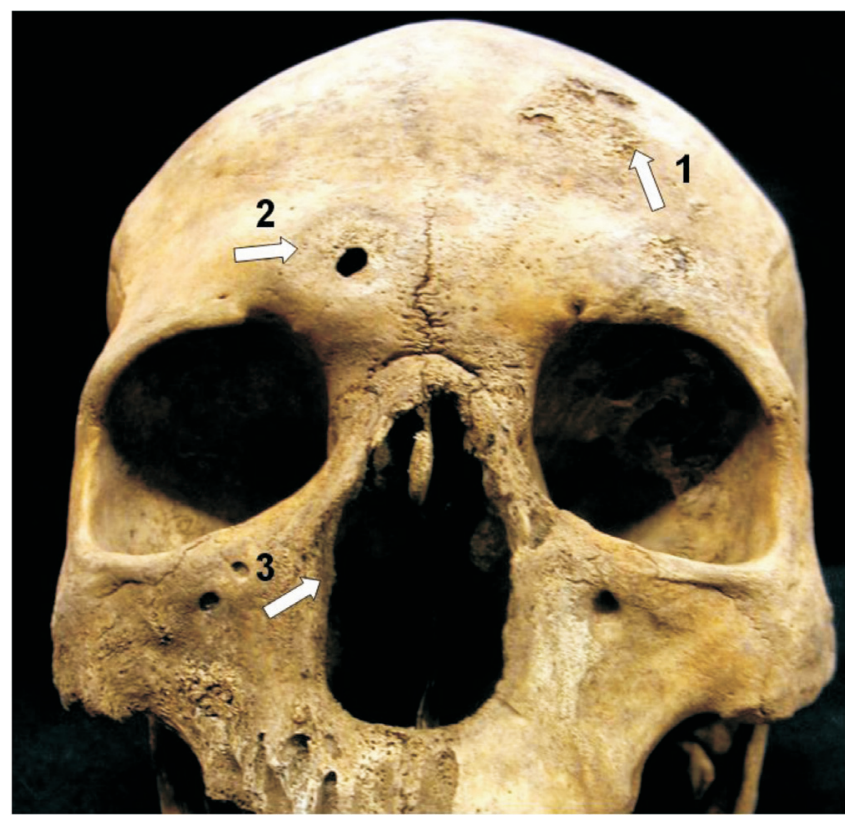

Fig. 2. Individual 214, evidence for VS: (1) "caries sicca" lesions on the frontal bone; (2) a necrotic lesion perforating the frontal bone; (3) extensive remodelling changes of the nasal aperture.

merus, the posterior part of the right proximal ulna and distally on the posterior shaft of the right radius.

Burial 217b (non-adult, 14-15 years old). This individual was buried in the lower layer of the collective pits Nos. 206 and 217. The entire skeleton was available for analysis. The frontal and nasal bones were porous in appearance, but no new bone formation or remodelling changes were observed. Post-cranially, the tibiae and fibulae had the "sabre shin" appearance - both tibiae had markedly thickened medial shafts, which had caused a rounded, bowed appearance of the anterior crest.

Burial 217e (female, 30-35 years old). This individual was also buried in the lower layer of the collective pit Nos. 206 and 217. The whole skeleton, except for the right fibula and the right hand, was available for analysis. Similarly to a number of other adult individuals described above, this female also had extensive "caries sicca" lesions on the frontal bone of the skull. Post-cranially, both tibiae were affected by extensive periosteal reactions and perforations likely caused by gummatous lesions (Fig. 3). The infection had also affected the right elbow joint.

\section{DISCUSSION}

The destructive lesions observed in Burial 139, with little evidence for new bone formation, might have been caused by tuberculosis. If affecting the skeleton, the infection is particularly common in the lower spine and the joint between the $5^{\text {th }}$ lumber vertebra and the sacrum (Ortner, 2003).

The pathological changes in burials 185, 209d, 212, 214, $217 \mathrm{~b}$, and $217 \mathrm{e}$ were characteristic of venereal syphilis (VS) in different stages. In individuals 185, 209d, and 212 the ap-

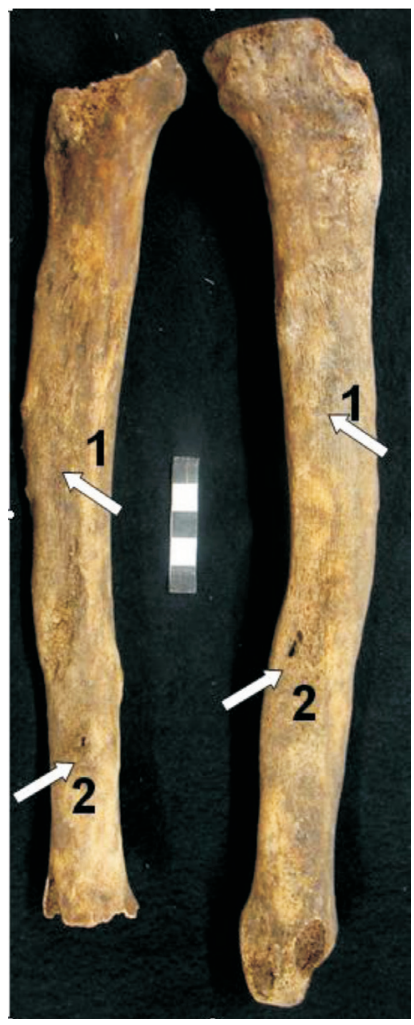

Fig.3. Individual 217e, evidence for VS on the tibiae: (1) a thick layer of lamellar bone; (2) perforating gummatous lesions (scale in $\mathrm{cm})$.

pearance and distribution of the lesions were suggestive of initial stages of VS, when only the frontal bone and the lower legs are usually affected.

In burial 214, although remodelling changes in the nasal aperture can be caused by various conditions, including leprosy, TB and VS (Ortner, 2003), the presence and the appearance of the lytic lesions in the skull, also called "caries sicca" (irregular, necrotic lesions on the outer table of the skull), as well as the distribution of other pathological changes, suggest the presence of tertiary VS. With regards to lytic lesions on the skull, it was observed that all of them had initiated on the outer table, thus supporting the diagnosis of VS; in TB, the lesions on the skull are more likely to affect the inner table first (Hackett, 1976). Since this individual did not have pathological changes specific to leprosy affecting the fingers and toes (Ortner, 2003), it is unlikely that the remodelling changes in the nasal aperture were caused by this infectious disease.

The lesions observed in the lower legs of burial $217 \mathrm{~b}$ could also have been caused by VS. Taking into account the age of the individual, late congenital VS is one of the possible diagnoses, although no specific dental enamel defects were present on the teeth; this form of the disease affects children aged between 5-15 years, after a long period of latency (Steinbock, 1976).

Finally, the distribution and appearance of the lesions in burial $217 \mathrm{e}$ suggested the presence of advanced VS. New bone formation on the lower legs had caused the "sabre-shin" appearance, which is characteristic in tertiary VS (Hackett, 1976). Although the changes observed in the left elbow joint could be related to a number of other condi- 
tions, asymmetrical joint lesions can be present in VS (Ortner, 2003).

The palaeopathological analysis of the skeletal population of the Riga Dome Church Cemetery revealed that at least one individual was suffering from TB at the time of death. Altogether, the spine was observable in 165 adult and 73 non- adult individuals (aged 5-19 years). Destructive changes that could have been caused by TB were only present in the individual from burial 139. In this case, the infection had affected the lower spine. It is possible that the presence of TB in other individuals could be found with the help of ancient DNA analysis, which is being used with considerable success in bioarchaeology (Zink et al., 2005). Indeed, it is possible that more individuals from this cemetery population had suffered from TB, but the limiting factor in detecting the disease by macroscopic observation alone is the lack of ribs due to the excavation strategy, as discussed above. So far, only three possible cases of TB have been reported in Latvian skeletal populations. For this reason, it has been suggested that most people with TB died shortly after the onset of the disease, without developing changes in the skeleton. It is also possible that there were different, acute forms of TB in the past, which did not affect the skeleton (Derums, 1988).

With regards to other specific infectious diseases, there were six individuals with changes likely caused by VS (Table 2). In two individuals, the changes were characteristic of the tertiary stage of VS $(214 ; 217 \mathrm{e})$, and three other adult individuals had pathological changes possibly caused by early VS (185; 209d; 212). One non-adult individual (217b) also had skeletal changes, particularly in the lower legs, possibly caused by late congenital VS. This is the first possible case of late congenital VS in the skeletal populations from Latvia. It has to be taken into account, however, that the actual number of people suffering from VS in medieval and post-medieval Riga could have been higher, the rates possibly nearing an epidemic. This is because tertiary syphilis only involves the skeleton in $20 \%$ of the affected people, and in 42-62.4\% the lesions are found in the skull (Steinbock, 1976). As a result, the disease is macroscopically undetectable in a large number of individuals.

The discussion about VS in palaeopathological literature has been ongoing for decades. Some researchers believe that the previously published data about the disease reaching Europe only after the return of Christopher Columbus

Table 2

DISTRIBUTION OF PATHOLOGICAL LESIONS INDICATIVE OF VENEREAL SYPHILIS ACCORDING TO HACKETT (1976)

\begin{tabular}{l|c|c|c|c|c}
\hline Burial /skeletal indicator & 185 & $209 \mathrm{~d}$ & 212 & 214 & $217 \mathrm{e}$ \\
\hline Nodes & + & + & + & + & + \\
Expansions & + & + & + & + & + \\
Superficial cavitations & & & & + & + \\
Carries sicca & n/a & + & + & + & +
\end{tabular}

$\mathrm{n} / \mathrm{a}$, the skull was not available for analysis from the New World in 1493 are inaccurate (Harper et al., 2011). In the case of the Riga Dome Church Cemetery, the dating of one of the collective pits (the upper layer of 206 and the lower layer of 217), in which two individuals with possible VS were buried, raises questions. No artefacts that could aid with the dating of the burials were found in this pit; just above it, however, there was an individual burial (204) that contained artefacts dating from the end of the $14^{\text {th }}$ to the beginning of the $15^{\text {th }}$ century AD (Tilko, 1998). If this date is correct, then the two individuals with VS from the collective pit (burials 217b and 217e) are earlier than the travels of Columbus. In order to discuss this situation in more detail, it is necessary to obtain a radiocarbon date from burial pit 217.

It is worth mentioning that all individuals with possible VS had been buried in a relatively small area by the northern wall of the church $\left(30 \mathrm{~m}^{2}\right)$. Three of them were buried in individual graves, and three in collective pits. It is possible that those buried in collective pits had died during a natural disaster (epidemic, famine) or a war affecting the city. This possibility is supported by the fact that none of the deceased were placed in a coffin. It is also possible that this area of the cemetery was reserved for those who died in shelters or hospitals, which also accommodated people who suffered from VS. Taking into account historical evidence, VS reached Livonia (the territory of Latvia and Estonia) in the end of the $15^{\text {th }}$ century/beginning of the $16^{\text {th }}$ century AD via land trade routes from Poland and Lithuania (Derums, 1988; Jankauskas, 1994). According to the palaeopathological evidence, however, having found cases of VS mainly in Riga, it is possible that the infection was brought to Riga via the sea shortly after the discovery of the New World by the Europeans, and had spread to the level of an epidemic by the $16^{\text {th }}$ century, as the first hospital for VS patients was opened in Riga in 1543 (Brennsohn, 1905).

This research has generated new and meaningful facts about infectious disease in the medieval population of Riga, which would not be possible to obtain by means other than palaeopathological analysis. The analysis of 274 individuals revealed that seven individuals (six adults and one nonadult) likely suffered from specific bacterial infections at the time of death. In five adults (four females and one male) specific changes likely caused by VS were found in the skull and the long bones, particularly the lower legs. A non-adult individual had changes in the lower legs possibly caused by late congenital VS. The chronology of these burials is not straight forward: according to archaeological data, at least two individuals could have been buried before the discovery of the New World by Columbus in 1493. It has to be taken into account, however, that archaeological dating using artefacts can be misleading, and that a radiocarbon date would be necessary to date the burials with more precision. Apart from the dating discrepancies, this research supports historical evidence about high prevalence of VS in the $16^{\text {th }}$ century Riga. Earlier research about the spread of VS in Eastern Europe has suggested that initially in the $16^{\text {th }}-17^{\text {th }}$ centuries VS only affected the wealthier popula- 
tion of the cities, who were exposed to a wider society (Jankauskas, 1994). In this case, VS was found among the poor population of Riga, who might have been patients of a shelter or a hospital.

Despite the relatively large number of individuals analysed during this research and also historical evidence for a high prevalence of leprosy in medieval and late medieval Riga, this infectious disease has not been found in the archaeological populations of Riga or Latvia. So far, no cases of leprosy have been reported from the Baltic States. It has to be taken into account that people suffering from leprosy could have been buried in cemeteries next to special leprosy hospitals or leprosaria. It is possible that in Riga, leprosy patients were accommodated in the St George's Hospital, which was located outside the city walls from the $14^{\text {th }}$ century onwards. The hospital also had some outbuildings, a church and a cemetery (Šterns, 1997).

This research has also yielded the first case of possible TB in Riga in the $15^{\text {th }}-17^{\text {th }}$ centuries. The macroscopic observations should be complemented with biomolecular analysis for the presence of M. tuberculosis DNA, and the genome of the bacterium if the result is positive. The results would be very important for a comparative analysis between ancient and contemporary TB, thus finding the possible origin of the TB types currently affecting the population of Latvia. To continue the research into infectious disease in the past, a multidisciplinary approach is necessary involving archaeology, palaeopathology, and molecular biology in order to answer the questions raised by this research, as well as to gain new data about how infectious diseases affected the past populations of Riga and Latvia.

\section{ACKNOWLEDGEMENTS}

The research was supported by the European Social Fund (ESF), Grant no. 2013/0039/1DP/1.1.1.2.0/13/APIA/VIAA/ 038

\section{REFERENCES}

Ascádi, G., Nemeskéri, J. (1970). History of Human Lifespan and Mortality. Akademiai Kiado, Budapest. 346 pp.

Bergmann, A. (1988). Die lepra und ihre Gefahr für Rīga. Baltische Monatsschrift. 34, 336-355.

Brennsohn, I. (1905). Die Aerzte Livlands von den ältesten Zeiten bis zur Gegenwart. Mitau (in German). 481 pp.

Brooks, S., Suchey, J. M. (1990). Skeletal age determination based on the os pubis: A comparison of the Acsadi-Nemeskeri and Suchey-Brooks methods. Hum. Evol., 5, 227-238.

Buckberry, J. L., Chamberlain, A. T. (2002). Age estimation from the auricular surface of the ilium: A revised method. J. Phys. Anthropol., 119, 231-239.

Buikstra, J. E., Ubelaker, D. H. (eds.) (1994). Standards for data collection from human skeletal remains. Proceedings of a Seminar at the Field Museum of Natural History. Arkansas Archaeological Survey Research Series, 44. Arkansas Archeological Survey, Fayetteville, Ark. 218 pp.
Cronberg, S. (1986). Infektioner. Mikrobiologi, klinik, terapi. Almqvist \& Wiksell, Stocholm. 518 pp.

Derums, V. (1988). Baltijas sencilvēku slimības un tautas dziedniecība [Ancient Baltic inhabitants: diseases and treatment]. Zināne, Rīga. 233 pp. (in Latvian).

Dunsdorfs, E. (1962). Latvijas vēsture, 1600-1710 [History of Latvia 1600-1700]. Daugava, Stockholm. 588 pp. (in Latvian).

Gerhards, G. (2005). Ventspils 15.-17. gadsimta iedzīvotāju bioarheologiskā izpēte [Bioarchaeological investigation of the $15^{\text {th }}-17^{\text {th }}$ century population of Ventspils]. Latvijas Vēstures Institūta Žurnāls, 3, 5-29 (in Latvian).

Hackett, C. J. (1976). Diagnostic Criteria of Syphilis, Yaws and Treponarid (Treponematoses) and of Some Other Diseases in Dry Bones: For Use in Osteo-Archaeology. Springer-Verlag, Berlin. 140 pp.

Harper, K. N., Zuckerman, M. K., Harper, M. L., Kingston, J. D., Armelagos, G. J. (2011). The origin and antiquity of syphilis revisited: An appraisal of Old World pre-Columbian evidence for treponemal infection. Amer. J. Phys. Anthrop., Suppl., 53, 99-133.

Jankauskas, R. (1994). Syphilis in Eastern Europe: historical and paleopathological evidence. In: Dutour, O, Palfi, G, Berato, J, Brun, J.-P. (eds.). L'origine de la syphilis en Europe: avant ou apre's 1493? [The origin of syphilis in Europe: before or after 1493?]. Editions Errance, Toulon, France, pp. 237-239 (in French).

Larsen, C. S. (1997). Bioarchaeology (Interpreting Behaviour from the Human Skeleton). University Press, Cambridge. 461 pp.

Lovejoy, C. O., Meindl, R. S., Mensforth, R. P., Barton, T. J. (1985). Multifactorial determination of skeletal age at death: A method and blind tests of its accuracy. Amer. J. Phys. Anthrop., 68, 1-14.

Meindl, R. S., Lovejoy, C. O. (1985). Ectocranial suture closure: A revised method for the determination of skeletal age at death based on the lateral-anterior sutures. Amer. J. Phys. Anthropol., 8, 57-66.

Ortner, D. J. (2003). Identification of Pathological Conditions in Human Skeletal Remains. Smithsonian Institution Press, Washington. 645 pp.

Ortner, D. J, Putschar, W. G. J. (1981). Identification of Pathological Conditions in Human Skeletal Remains. Smithsonian Institution Press, Washington. $500 \mathrm{pp}$.

Phenice, T. W. (1969). A newly developed visual methods of sexing the os pubis. Amer. J. Phys. Anthropol., 30, 297-301.

Roberts, C. A. (2002). Palaeopathology and archaeology: The current state of play. British Archaeological Reports. British Series 1046. Archaeopress, Oxford, pp. 1-20.

Roberts, C. A, Manchester, C. (2005). The Archaeology of Disease. 3rd edn. Sutton Publishing, Stroud. 338 pp.

Scheuer, L., Black, S. (2000). Developmental Juvenile Osteology. Academic Press, London. 587 pp.

Steinbock, R. T. (1976). Paleopathological Diagnosis and Interpretation: Bone diseases in ancient human populations. Charles C. Thomas, Springfield, Illinois. $423 \mathrm{pp}$.

Šterns, I. (1997). Latvijas vēsture 1290-1500 [History of Latvia 1290-1500]. Daugava, Rīga. 740. lpp. (in Latvian).

Tilko, S. (1998). Apbedī̌̌anas tradīcijas Doma viduslaiku kapsētā [Mortuary practices in the Medieval Cemetery of the Riga Dome Church]. In: Senā Rìga 1: Pètījumi pilsētas arheoloǵijā un vēsturēe. Latvijas vēstures institūta apgāds, Rīga, 273.-288. lpp. (in Latvian).

Zarina, G. (2009). Latvijas iedzīvotāju paleodemogrāfija 7. g.t. pr. Kr. 1800. $g$. [Palaeodemography of the Inhabitants of Latvia $7^{\text {th }}$ mill. BC 1800 AD]. Latvijas vēstures institūta apgāds, Rīga. 247. lpp. (in Latvian).

Zink, A. R., Grabner, W., Nerlich, A. G. (2005). Molecular identification of human tuberculosis in recent and historic bone tissue samples: The role of molecular techniques for the study of historic tuberculosis. Amer. J. Phys. Anthropol., 126, 32-47. 

LATVIJĀ

Šì raksta mērḳis ir prezentēt datus par infekcijas slimībām Rīgā vēlajos viduslaikos, balstoties uz osteoloǵiskā materiāla paleopatoloğisko izpēti, kas iegūts Doma baznīcas kapsētas izrakumos. Veikta 274 indivīdu skeletu makroskopiskā izpēte, indivīda dzimuma, vecuma un patoloğiju diagnosticēšanai izmantojot vispārpieņemtos kritērijus un metodes. Tuvāk raksturoti septiṇi indivīdi, kuru skeletos konstatētās patolog̣ijas saistāmas ar kādu no baktēriju izraisītajām infekcijas slimībām. Četrām sievietēm un vīrietim kaulu destruktīvās izmaiņas uz galvaskausa ārējās virsmas un ekstremitāšu garajos kaulos raksturīgas venēriskajam sifilisam (VS). 14-15 gadus vecam pusaudzim konstatēts vēlīnais iedzimtais VS. Visi šie indivīdi apbedīti pie Doma baznīcas ziemeḷu sienas nelielā teritorijā, kas, iespējams, ir bijusi apbedīšanas vieta kāda hospitāla vai patversmes iemītniekiem. Iegūtie dati apstiprina vēsturiskos avotus par VS epidēmisko izplatību Rīgā 16./17. gadsimtā. Vienam vīrietim kaulos konstatētās destruktīiās izmaiņas saistāmas ar kaulu tuberkulozi (TB). Šim indivīdam TB lokalizējas mugurkaula jostas dạ̦ā. Līdz šim TB Rīgas arheoloğiskajā populācijā nebija konstatēta. Šāda veida pêtījums par Latvijas iedzīvotājiem līdz šim nav veikts, tāpēc iegūtie rezultāti sniedz kvalitatīvi jaunu informāciju par infekcijas slimību izplatību senatnē un būs zināms atskaites punkts turpmākajiem pētījumiem, t.sk. patogēno mikroorganismu DNS noteikšanā. 